\title{
Prospected epigenetic moderators from natural sources and drug of class NSAIDS as effective treatment options to Prostate cancer
}

\author{
Vaibhav Dubey ${ }^{1}$, Richard Owusu-Apenten ${ }^{2}$, Shipra Tripathi ${ }^{3}$, Udaya Pratap Singh ${ }^{4}$, Alok \\ Semwal ${ }^{5 \bowtie}$ \\ ${ }^{I}$ Volhart Health Care Pvt. Ltd., Department of Research and Development, Sitapur Road Yojna, Lucknow,UP, India \\ ${ }^{2}$ Faculty of Life and Health Sciences, School of Biomedical Sciences, University of Ulster, Coleraine, BT52 1SA, United Kingdom \\ ${ }^{3}$ Babu Banarasi Das Northern India Institute of Technology, Department of Pharmacy, Faizabad Road, Lucknow,UP, India \\ ${ }^{4}$ Sam Higginbottom University of Agriculture, Technology and Sciences, Department of Pharmaceutical Sciences, Allahabad, Naini, UP, India \\ ${ }^{5}$ Department of Pharmacy, Himachal Institute of Pharmacy, Paonta Sahib-173025, H.P India
}

\section{ARTICLE INFO}

Article history:

Received 12 April 2017

Received in revised form 10 May 2017

Accepted 8 June 2017

Available online 1 July 2017

\section{Keywords:}

Prostate cancer

NSAIDS

AKR1C

GSH/GST

DNA hypermethylation

\section{ABSTRACT}

Prostate cancer (PC) is one of the most common and leading cancer amongst the males all around the world. Depending upon it long latency and cost involved in its management and treatment, there is extensive need for more personalized and economical therapeutic approach for its effective therapy. The current review here discusses agents from natural dietary sources and drug class Non-Steroidal Antinflammatory (NSAIDS) that bears chemopreventive potential to regulate PC progression \& tumour development and therefore could be devised into effective future treatment strategy against PC along with its metastatic castration-resistant form. Based on the literature search the therapeutic scope of selected agents are delineated, sighting their previous activity and prospects as epigenetic moderators in specific to particular PC causing biomarkers like over expression of AKR1C3, lost intracellular glutathione/glutathione-stranferases(GSH/GST) expression, DNA hypermethylation, aberrant cell proliferation and other related factors that are thought to potentiate and aggravate the onset of PC like smoking and use of other narcotics products.

\section{Background}

Prostate cancer (PC) is the fourth most common and second most prevalent cancer amongst males worldwide. In estimation to its mortality rates it is the 8th most consistent cause of cancer deaths around the world. It was estimated in year 2012 that around 1111000 new cases were diagnosed with PC out of which 307000 were dead. While, New Zealand/Australia toped the chart with highest diagnosed cases, Caribbean islands and sub-Saharan African countries had witnessed to have maximum PC related mortality rates[1,2].

Corresponding author: Alok Semwal, Department of Pharmacy, Himachal Institute of Pharmacy, Paonta Sahib-173025, H.P India.

E-mail: alokm.pharm01@gmail.com
There has been number of prominent biomarkers that have been associated at certain stages leading to onset and progression of PC. Some to be seriously considered includes over expression of AKR1C3 enzyme leading to castrate resistant PC. AKR1C3 originally functions via reducing 4-androstene-3, 17-dione $(\triangle$ (4)Adione) to the androgen receptor (AR) ligand testosterone i.e. fostering conversion of ketones and aldehyde to respected alcohols using NADH/NADPH as cofactors[3-5]. It also bear critical role catalyzing reduction of steroids, prostaglandins,PGH2, D2, phenantherenequinone, oxidation 9-alpha,11-beta-PGF2 to PGD2 and pathogenesis of certain diseases like diabetic complications, steroid hormone dependent malignancies including PC via regulating/controlling cell proliferation/differentiation etc[6-8]. Aberrant up regulation in normal AKR1C3 enzyme and its related gene functionality in PC is mainly due to intracellular synthesis 
of AR ligands which further leads to stimulation of proliferation through AR signalling and later promoting PC progression to castrate resistant state[3,9].

DNA promoter Hypermethylation in GST (Glutathione-STranferases) enzyme is another biomarker designated to cause prostate cancer which results in the silencing of tumour suppressor gene (GSTP1)[10,11]. -This gene originally act by protecting normal cells from toxic and carcinogenic agents via promoting their conjugation with Glutathione (GSH) substrates further transforming them to less toxic and easily excreted metabolites. It also protect DNA from oxidative damage through intrinsic pathway activity by conversion of toxic peroxides to non-active alcohol and reducing lipid hydroperoxides via glutathione peroxidases activity which is Se-independent to detoxifying end products like 4-hydroxynonenal (4-HNE) by lipid peroxidation. Abruption/inactivation/low expression of this enzyme leads the normal prostate cells for direct exposure to toxins, mutagens and carcinogenic agents later transforming them to cancerous form[12].

There are chances that these selected androgen and estrogens biomarkers might work synergistically upon the onset or at certain stages to cause PC and its progression, making it more resistant and tough to treat. There are studies focussing on treating and regulating these biomarkers individually at certain extent through both conventional (Chemo and Hormonal therapy) and nonconventional (Via Natural agents) therapeutic methods but none showed targeting both enzymatic biomarkers simultaneously. PC is considered to be immensely dependent upon the age with individuals mostly over 50 years[13]. However, It might not just the age which bears impact on initiation of these biomarkers causing PC, but there may be other factors like life style, diet, genetic variability, cancer history in family, Hormone imbalance etc which are also needed to be addressed and could potentiate the risk by encouraging both enzyme based biomarker working simultaneously for onset, aggravation and progression of PC. In some of the latest study it was elucidated that individuals smoking tobacco has vast chances to be diagnosed with prostate cancer with increase of biochemical recurrence, distant metastasis etc[14-16].

There are multiple conventional treatments options currently available in form of Hormonal and chemotherapy, drugs like Docetaxel, goserelin, entazalutamide, Degarelix, Mitoxantrone, Epirubicin, Estrmustine, Abiraterone Acetate etc[17] are widely in use for treating these biomarkers causing PC separately. However, these drug treatment options are limited to efficiency with the negative feature of high toxicity and adverse effects with chronic impact as in case of some like abiraterone acetate and docetaxel[18]. Therefore, a method using bioactive agents from natural dietary sources[19] and drugs belonging to class of NSAIDs(OTC) which has not been researched effectively to their potentials in reducing risk to Prostate Cancer and its cell survival in recent times[20], may be considered one of the novel ways for chemoprevention in healthy tissue and therapeutic option for treating PC. The screening and selection of the potential natural agents[21] and NSAIDS class of drugs[22,23] could be based on their potential to cause reversal of over expressed AKR1C3 enzyme and inducing poorly expressed GST/ GSH activity in PC cell lines (LNCaP and PC-3). Natural agents like epigallocatechin-3gallate[24-28], curcumin[29-33], resveratrol[3438], quercetin[39,40], genistein[41,42] and drugs like Aspirin[43,44], meclofenamic acid[45] atorvastatin[46,47], celecoxib[48,49], Indomethacin[3,50-52], diclofenac and naproxen[53-56] belonging to class NSAIDS shown immense potential to be anti cancerous agents and therefore could be prospected to work efficiently regulating both the androgen and estrogens biomarkers as potential human prostate cancer treatment options.

Based on this fact the current review focuses on to give a insight on prospected naturally occurring dietary sources along with agents belonging to class of NSAIDS that could be devised to potential treatment strategy against prostate cancer acting as epigenetic moderators and had shown abilities to down regulate overexpression of AKR1C3 enzyme caused by intracellular synthesis of AR ligands, induce intracellular GSH/GST level lost due to hypermethylation i.e. phase II detoxification activity as being an potent DNA methylation inhibitors(DMI'S), apoptosis resulting to prostate cancer cell death, inhibition of cell proliferation and lastly eliminating the negative impact of factors which might synergistically aggravate or act to be a prominent initiator for these biomarkers causing PC such as Tobacco smoking.

\section{Natural dietary agents}

Owing to the multifactorial applications of agents from natural sources in the field of medicine therefore, developing plant based bioactive compounds as drugs could be a novel method devising a therapeutically effective and cheaper treatment options for PC and a possibility to target biomarker based therapy.

There are numbers of evidences suggesting that plant based treatments could be common approaches to treat and prevent PC. Research evidences shows potential extracts from plants such as Carica papaya[57], Papaver somniferum[58], Dimocarpus Longan Lour[59] etc. carry's healthy insight to be developed into effective treatment option for PC. However, in spite decades of research on variety of such plants based agents, steadfast and economical solutions still needed to be addressed immensely. Considering the fact the agents described here are amongst the most desirable and ideal to be developed as biomarker based anti cancer agents.

\subsection{Epigallocatechin-3-gallate (EGCG)}

The major polyphenolic constituent present in green tea. It has shown its marked potential for further development as a perfect dietary agent in treatment and prevention of cancer especially Prostate Cancer (PC). Based on the latest studies, regular intake of green tea might reduce the chances of developing PC in males[27,28,60,61]. EGCG has already been proven to have potential 
anticancerous effects with the major ability to induce apoptosis in both androgen sensitive and insensitive PC cell lines with cell cycle arrest and dysfunction, delaying DNA oxidative damage etc in both in vivo and in vitro studies[62-66]. Moreover EGCG has also demonstrated their ability to down regulate AR acetylation in androgen dependent PC via modulation in histone acetyl tansferases activity resulting into $\mathrm{PC}$ cancer cell death, AR regulated gene transcription and suppressed agonist-depenedent AR activation. It also led to suppression in histone methylation preventing cell survival/proliferation in skin cancer cells by inducing apoptosis[67]. In studies[68,69] EGCG has potentially reactivated hypermethylatedsilenced genes via inhibition of DNA methyltranferses (DNMT) in cancer cell lines including PC-3 and therefore could be prospected to restore GST/GSH activity lost in other PC cell lines[70]. The efficient anticancer potential of EGCG has gained it lot of popularity in recent times encouraging its utilization in treating and preventing castrate resistant PC likely to be caused due to overexpressed AKR1C3 enzyme, as suggested by[71] EGCG bears the ability to regulate this abrupt expression of AKR1C3 enzyme in hormone dependent malignancies including PC with the vital ability to minimise potential risk factors to the disease like blocking Nicotine/tobacco induced cancer proliferation via alfa 9-nicotinic acetylcholine receptor in breast cancer cells and inducing marked dose dependent decrease in nicotine-DNA adducts[72-74].

\subsection{Curcumin (diferuloylmethane)}

It is a polyphenolic compound obtained from the rhizome of the plant Curcuma longa (Turmeric). It is a yellow naturally occurring spice which is widely used as food and medical agent in Indian Ayurvedic medicine and also Chinese medicine[75]. Researches utilizing curcumin confirm its ability for being one of the potential natural chemopreventive agents at different stages of prostate cancer[76]. Being the molecule of pleiotropic nature, it regulates multiple pathways involved in signalling of cells in the survival and growth of prostate cancer cell type. Curcumin has shown marked impact on both androgen sensitive and independent prostate cell lines[77,78]. Additionally, it has ability to inhibit cell viability simultaneously inducing lost GST/GSH activity in LNCaP PC cell lines and acting as a potent DNA hypermethylation inhibitor[33]. Moreover, recent studies has shown utilization of curcumin in nano formulation and microemulsified forms to increase its bioavailability and site specific action in particular to cancer cells[32,79,80].Curcumin and its related analogues has also been witnessed to induce epigenetic changes in tumour cells including PC with ability to modulate of histone acetylation by inhibiting histone acetylase[ [81,82], inducing apoptosis[83], Downregulation of AR and its binding ability[82], regulation of epidermal growth factor receptor(EGFR) tyrosine kinase activity[84,85],inhibition of angiogenesis/vascular endothelial growth factor(VEGF)[86,87], inhibition of cell proliferation in androgen independent and dependent PC cell lines via modulation of Wnt transcriptional activity medicated by low expression of protein in Wnt transcriptional complex[77,88-93]. However, the effect of curcumin still remain dubious specifically to intracellular synthesis of AR ligands which leads to stimulation of proliferation through AR signalling and overexpression of AKR1C3 further promoting PC to castrate resistant state. In relation to factor like smoking tobacco or nicotine which are thought to increase the risk for PC, curcumin as being one of the best prospected chemopreventive natural dietary agent is also found to be eliminating the negative impacts associated to smoking via blocking nicotineinduced activation of AKT/MTOR pathway in HNSCC retarding cell cycle, proliferation and metastasis[14,15,94,95].

\subsection{Resveratrol(RSV)}

A polyphenolic natural agent vastly present in fruits like grapes, blueberries and dietary products like pistachios, peanuts etc[96]. In recent studies, RSV has been found to inhibit cell growth/proliferation via cell cycle arrest and induction of apoptosis, angiogenesis in several human cancer cell lines such as A549(Lung),BT20(Breast) including PC cell lines PC-3 and DU145,LNCaP etc[37,97-99]. RSV is also associated to inhibit AR related transcriptional activity in both androgen dependent and independent prostate cancer with stimulation in expression of PTEN through AR inhibition. Additionally it inhibits epidermal growth factor (EGFR) phosphorylation by binding to EGFR directly resulting to decreased AKT phosphorylation in androgenindependent prostate cancer[36]. RSV has shown to suppress EGFR-dependent Erk1/2 activation stimulated by porbol ester and EGF in androgen independent PC-3 PC cell lines[99-101].Moreover, In past researches it has been found to restores the p53 acetylation via downregulating the overexpression of Metastatis-associated protein1(MTA1) which is linked to tumor aggressiveness and metastasis in PC cell lines[102]. As it is previously known in past researches hypermethylation in DNA results in silencing of tumor suppressor genes like GSTP1, RSV is also found to be restoring the functionality/enzymatic activity of such genes in different cancer s including PC via inhibition of DNA methyltransfereses enzyme[103-106]. Apart in Neuroblastoma solid tumor in pediatric RSV displayed ability to inhibit histone methytransferase EZH2 which is aberrantly over expressed in Neuroblastoma tumor further leading to its suppression[107]. There have been none of the studies suggesting the direct impact of RSV on overexpresssed AKR1C3 enzyme. However, RSV is found to be highly active against the risk factors causing PC like Smoking tobacco/nicotine via exerting antiinflamtory, antioxidant and anti apoptotic effects and inhibiting nicotine based pathways[108-110].

\section{OTC(Over the Counter) NSAIDS (Non-Steroidal Ant inflammatory) Agents}

Anti-cancer effect of NSAIDS in animals model was first reported 
in 1972[111]. Since then there has been multiple number of researches done to prove NSAIDS a relatively non-toxic drugs, to prevent cancer. Researches in past including NSAIDs and related drugs has demonstrated their significant therapeutic potency in reducing cancer mortality in meta-analysis trials in human[112,113].

There are also strong evidences that show NSAIDs lowering risk to cancers like prostate via lowering prostate specific antigen (PSA), colorectal, breast and lung etc. However, certain meta-analysis also suggested its association with an increased risk of prostate and other cancer[114] predicting its dubious therapeutic potential which is still needed to be stated adequately in the prospects to develop and use less toxic and economically affordable treatment option for cancer[115].

\subsection{Aspirin}

It is one of the most common and easily available over the counter drug belonging to class of NSAIDS also known as acetylsalicylic acid sub-classed under Salicylic acid derivatives. In recent studies ,aspirin beside having anti-inflammatory, anti-pyretic effects via irreversible inactivation of both cycloxygenase(COX) 1 and 2 enzyme in multiple observational studies and controlled randomized trial has also shown promise to be effective as chemopreventive agent like in cancer of prostate, breast, pancreatic and colon either in its original or as modified form[116-121].

In specific to prostate cancer aspirin has been found to be associated with inhibiting cell proliferation in variety of its cell lines like PC-3 and DU145,LNCaP[19,122,123]. Multiple number of cohort studies suggests its ability in terms of reducing mortality and chances of recurrence of prostate cancer ultimately justifying its therapeutic potential as future treatment strategies for this deadly disease[43,124126].

Moreover, in both in vitro and in vivo studies, aspirin has been found to be associated with reversing tumour suppressor gene hypermethylation in variety of cancer tissues[100,127-130]. At the histone level, it has also been reported to induce and inhibit of deacetylases with direct acetylation of histones[131-133]. Studies has also reported Aspirin inhibiting AR related transcriptional activity in both androgen dependent and independent prostate cancer[134] while regulating the aberrant overexpression of AKR1C3 gene in certain breast cancer cell lines[135].

Additionally, its ability to induce Phase - 2 detoxification enzymes Glutathione-S Tranferases(GST) in normal cells which is under expressed in variety of cancer cell lines including Prostate cancer facilitates combating carcinogenics agents[97,136]. However the effect of aspirin against the risk factors causing PC like Smoking tobacco/ nicotine via exerting anti-inflammatory, anti apoptosis is still unclear regards to researches done in past[137].

\subsection{Indomethacin}

Similar to aspirin, indomethacin is also one of the most used anti-inflammatory drugs belonging to class NSAIDS sub classed under Acetic acid derivative. Multiple numbers of studies has suggested its marked potential for further development as a perfect chemopreventive agent as for treatment of cancer.

Based on the latest studies indomethacin has been found to induce apoptosis and inhibiting cell growth in the EC109 esophageal and ovarian cancer cells[138,139]. Similarly, it has also been observed to reduce breast tumor via COX-independent pathway[140]. Most of the action of indomethacin has been found to be similar to Aspirin in terms of its chemopreventive and anticancer activity.

In particular to prostate cancer Indomethacin and its subsequent analogues are witnessed to inhibit overexpression AKR1C3/ Prostaglandin F Synthase in castrate resistant-Resistant Prostate cancer[6,52,141]. Although there has been no researches predicting its role on induction of phase- 2 detoxification enzymes in body cells and also its ability, to induce or to inhibit of deacetylases with direct acetylation at histonic levels. However, along with other NSAIDS indomethacin has been found to minimize the risk factors via its antiinflammatory efficacy,which are thought to trigger and potentiate the initiation and progression of prostate cancer in human like smoking,tabocco/Nicotine usage[142,143].

\section{Conclusion}

The scope of dietary natural agents and drugs belonging to class NSAIDS as a steadfast therapeutically option for PC is very much of interest and encouraging for researchers around the world. Concerning to the limitations to the currently in place conventional PC treatment strategies there is a vital requirement to explore such out of the line agents that could potentially devised into a novel futuristic cancer therapy. PC based on its long latency, visible tumour growth which is comparatively easy to monitor as to other cancer, could be an ideal choice for agents to research both clinically as well as in the research laboratory. The Preliminary data in the review shows the immense potential for the agents and their considerable activity to individual PC causing biomarkers. However, such cancer interventions could be time taking and require rigorous multiple phases of clinical study before can be recommended as useful chemopreventive/treatment strategies for patients. Thus, a confirmational activity for agents along with their optimal doses, usage, administration profiling etc are very much desirable through a well designed clinical trials.

\section{Conflict of interest statement}

The authors report no conflict of interest.

\section{References}

[1] Cancer Research UK. Prostate cancer incidence in Europe and worldwide. 2014. [Online]. Available from: http://www.cancerresearchuk.org/healthprofessional/cancer-statistics/statistics-by-cancer-type/prostate-cancer/ incidence\#heading-Four. [Accessed 20th April 2017].

[2] Ferlay J, Soerjomataram I, Ervik M, Dikshit R, Eser S, Mathers C, et al. 
GLOBOCAN 2012 v1.0, Cancer Incidence and Mortality Worldwide: IARC Cancer Base No. 11. Lyon: International Agency for Research on Cancer; 2013. [Online]. Available at: http://globocan.iarc.fr [Accessed on 24th April 2017].

[3] Byrns MC, Steckelbroeck S, Penning TM. An indomethacin analogue, $\mathrm{N}$-(4-chlorobenzoyl)-melatonin, is a selective inhibitor of aldo-keto reductase 1C3 (type 23 -HSD, type $517 \beta-\mathrm{HSD}$, and prostaglandin $\mathrm{F}$ synthase), a potential target for the treatment of hormone dependent and hormone independent malignancies. Biochem Pharmacol 2008; 75(2): 484-493.

[4] Yepuru M, Wu Z, Kulkarni A, Yin F, Barrett CM, Kim J, et al. Steroidogenic enzyme AKR1C3 is a novel androgen receptor-selective coactivator that promotes prostate cancer growth. Clin Cancer Res 2013; 19(20): 5613-5625.

[5] Powell K, Semaan L, Conley-LaComb MK, Asangani I, Wu YM, Ginsburg KB, et al. ERG/AKR1C3/AR constitutes a feed-forward loop for AR signaling in prostate cancer cells. Clin Cancer Res 2015; 21(11): 2569-2579.

[6] Adeniji AO, Chen M, Penning TM. AKR1C3 as a target in castrate resistant prostate cancer. J Steroid Biochem Mol Biol 2013; 137: 136-149.

[7] Skarydova L, Hofman J, Chlebek J, Havrankova J, Kosanova K, Skarka A, et al. Isoquinoline alkaloids as a novel type of AKR1C3 inhibitors. $J$ Steroid Biochem Mol Biol 2014; 143: 250-258.

[8] Penning TM. Mechanisms of drug resistance that target the androgen axis in castration resistant prostate cancer (CRPC). J Steroid Biochem Mol Biol 2015; 153: 105-113.

[9] Grist E, de Bono JS, Attard G. Targeting extra-gonadal androgens in castration-resistant prostate cancer. J Steroid Biochem Mol Biol 2015; 145: 157-163.

[10] Pellacani D, Kestoras D, Droop A, Frame F, Berry P, Lawrence M, et al. DNA hypermethylation in prostate cancer is a consequence of aberrant epithelial differentiation and hyperproliferation. Cell Death \& Differentiation 2014; 21(5): 761-773.

[11] Maldonado L, Brait M, Loyo M, Sullenberger L, Wang K, Peskoe SB, et al. GSTP1 promoter methylation is associated with recurrence in early stage prostate cancer. J Urol 2014; 192(5): 1542-1548.

[12] Singh S, Shukla GC, Gupta S. MicroRNA regulating glutathione S-transferase P1 in prostate cancer. Curr Pharmacol Report 2015; 1(2) 79-88.

[13] Cancer Research UK. Prostate cancer risks and causes. 2014 [Online]. Available from: http://www.cancerresearchuk.org/aboutcancer/type/prostate-cancer/about/prostate-cancer-risks-and-causes [Accessed 20th April 2017].

[14] Steinberger E, Kollmeier M, McBride S, Novak C, Pei X, Zelefsky MJ. Cigarette smoking during external beam radiation therapy for prostate cancer is associated with an increased risk of prostate cancer-specific mortality and treatment-related toxicity. BJU Int 2015; 116(4): 596-603.

[15] Polesel J, Gini A, Dal Maso L, Stocco C, Birri S, Taborelli M, et al. The negative impact of tobacco smoking on survival after prostate cancer diagnosis. Cancer Causes \& Control 2015; 26(9): 1299-1305.

[16] Karunasinghe N, Han DY, Goudie M, Zhu S, Bishop K, Wang A, et al. Prostate disease risk factors among a New Zealand cohort. J Nutrigene
Nutrigenomics 2012; 5(6): 339-351.

[17] Cancer Research UK. Treating Prostate Cancer. 2014. [Online]. Available at: http://www.cancerresearchuk.org/about-cancer/type/ prostate-cancer/treatment/ [Accessed 20th April 2017].

[18] Leibowitz-Amit R, Templeton AJ, Alibhai SM, Knox JJ, Sridhar SS, Tannock IF, et al. Efficacy and toxicity of abiraterone and docetaxel in octogenarians with metastatic castration-resistant prostate cancer. $J$ Geriatr Oncol 2015; 6(1): 23-28

[19] Adhami VM, Mukhtar H. Prostate cancer chemoprevention by dietary agents: advocating a personalized multi-agent approach. critical dietary factors in cancer chemoprevention. Switzerland: Springer International Publishing; 2016, p.13-29.

[20] Basler JW, Piazza GA. Nonsteroidal anti-inflammatory drugs and cyclooxygenase- 2 selective inhibitors for prostate cancer chemoprevention. J Urol 2004; 171(2): S59-S63.

[21]Al-Mahmood AA, Shu L, Kim H, Ramirez C, Pung D, Guo Y, et al Prostate cancer and chemoprevention by natural dietary phytochemicals. J Chin Pharmaceut Sci 2016; 25(9): 633-650.

[22] Ko C, Lan S, Lu Y, Cheng T, Lai P, Tsai C, et al. Inhibition of cyclooxygenase-2-mediated matriptase activation contributes to the suppression of prostate cancer cell motility and metastasis. Oncogene 2017; doi:10.1038/onc.2017.82.

[23] Zegelbone PM, Reljic T, Wilson D, Mhaskar R, Miladinovic B, Kumar A, et al. Chemoprevention agents for prostate cancer. The Cochrane Library; 2016.

[24] Sanna V, Singh CK, Jashari R, Adhami VM, Chamcheu JC, Rady I, et al. Targeted nanoparticles encapsulating (-)-epigallocatechin-3-gallate for prostate cancer prevention and therapy. Sci Rep 2017; 7: 41573.

[25] Lee P, Ng C, Liu Z, Ho W, Lee M, Wang F, et al. Reduced prostate cancer risk with green tea and epigallocatechin 3-gallate intake among Hong Kong Chinese men. Prostate Cancer Prostatic Dis 2017; doi: 10.1038/pcan.2017.12. [Epub ahead of print].

[26] Moses MA, Henry EC, Ricke WA, Gasiewicz TA. The heat shock protein 90 inhibitor, (-)-epigallocatechin gallate, has anticancer activity in a novel human prostate cancer progression model. Cancer Prev Res (Phila) 2015; 8(3): 249-257.

[27] Fujiki H, Imai K, Nakachi K, Sueoka E, Watanabe T, Suganuma M. Innovative strategy of cancer treatment with the combination of green tea catechins and anticancer compounds. Cancer Cell \& Microenvironment 2015; 2(4). doi: 10.14800/ccm.886

[28] Fujiki H, Sueoka E, Watanabe T, Suganuma M. Primary cancer prevention by green tea, and tertiary cancer prevention by the combination of green tea catechins and anticancer compounds. J Cancer prevent $2015 ; 20(1): 1-4$

[29] Yan J, Wang Y, Jia Y, Liu S, Tian C, Pan W, et al. Co-delivery of docetaxel and curcumin prodrug via dual-targeted nanoparticles with synergistic antitumor activity against prostate cancer. Biomedicine \& Pharmacotherapy 2017; 88: 374-383.

[30] Yang C, Ma X, Wang Z, Zeng X, Hu Z, Ye Z, et al. Curcumin induces apoptosis and protective autophagy in castration-resistant prostate cancer cells through iron chelation. Drug Design, Develop Therapy 2017; 11: 431 . 
[31]Jordan BC, Mock CD, Thilagavathi R, Selvam C. Molecular mechanisms of curcumin and its semisynthetic analogues in prostate cancer prevention and treatment. Life Sci 2016; 152: 135-144.

[32] Dubey V, Owusu-Apenten R. Enhanced growth-inhibitory effect of microemulsified curcumin formulation in human prostate cancer $\mathrm{LNCaP}$ Cells. British J Pharmaceut Res 2015; 5(3): 209-216.

[33] Dubey V, Owusu-Apenten R. Curcumin restores glutathione-Stransferase activity for $\mathrm{LNCaP}$ prostate cancer cells. Pure Appl Chem Sci 2014; 2(2):61-72.

[34] Vancauwenberghe E, Noyer L, Derouiche S, Lemonnier L, Gosset P, Sadofsky LR, et al. Activation of mutated TRPA1 ion channel by resveratrol in human prostate cancer associated fibroblasts (CAF). $\mathrm{Mol}$ Carcinog 2017.DOI: 10.1002/mc.22642.

[35] Saralkar P, Dash AK. Alginate nanoparticles containing curcumin and resveratrol: Preparation, characterization, and in vitro evaluation against DU145 prostate cancer Cell Line. AAPS Pharm Sci Tech 2017: 1-10.

[36] Dhar S, Kumar A, Li K, Tzivion G, Levenson AS. Resveratrol regulates PTEN/Akt pathway through inhibition of MTA1/HDAC unit of the NuRD complex in prostate cancer. Biochimica et Biophysica Acta (BBA)Molecular Cell Research 2015; 1853(2): 265-275.

[37] Selvaraj S, Sun Y, Sukumaran P, Singh BB. Resveratrol activates autophagic cell death in prostate cancer cells via downregulation of STIM1 and the mTOR pathway. Mol Carcinog 2015.DOI: 10.1002/ mc. 22324

[38] Cimino S, Russo GI, Reale G, Urzì D, Castelli T, Favilla V, et al. Pharmacological role of dietary polyphenols in prostate cancer chemoprevention. Critical dietary factors in cancer chemoprevention. Springer; 2016, p. 239-251.

[39] Baruah MM, Khandwekar AP, Sharma N. Quercetin modulates Wnt signaling components in prostate cancer cell line by inhibiting cell viability, migration, and metastases. Tumor Biol 2016; 37(10):1402514034.

[40] Yang F, Song L, Wang H, Wang J, Xu Z, Xing N. Combination of quercetin and 2-methoxyestradiol enhances inhibition of human prostate cancer LNCaP and PC-3 cells xenograft tumor growth. PloS one 2015; 10(5): e0128277.

[41] Carole S, Schnekenburger M, Mazunder A, Teiten M, Kirsch G, Dicato M, et al. 4-Hydroxybenzoic acid derivatives as HDAC6-specific inhibitors modulating microtubular structure and HSP90a chaperone activity against prostate cancer. Biochem Pharmacol 2016; 99: 31-52.

[42] Jang CH, Schmidt C, Wu C. Transcriptome profiling of human prostate cancer cell line LNCaP treated with individualSoy isoflavones or their combination. FASEB J 2015; 29(1 Supplement): 665.17.

[43]Skriver C, Dehlendorff C, Borre M, Brasso K, Sørensen HT, Hallas J, et al. Low-dose aspirin or other nonsteroidal anti-inflammatory drug use and prostate cancer risk: a nationwide study. Cancer Causes \& Control 2016; 27(9): 1067-1079.

[44] Assayag J, Pollak MN, Azoulay L. The use of aspirin and the risk of mortality in patients with prostate cancer. J Urol 2015; 193(4): 12201225 .

[45] Delgado-Enciso I, Soriano-Hernández AD, Rodriguez-Hernandez A, Galvan-Salazar HR, Montes-Galindo DA, Martinez-Martinez R, et al. Histological changes caused by meclofenamic acid in androgen independent prostate cancer tumors: evaluation in a mouse model. International braz j urol 2015; 41(5): 1002-1007.

[46] Chen X, Liu Y, Wu J, Huang H, Du Z, Zhang K, et al. Mechanistic Study of Inhibitory Effects of Atorvastatin and Docetaxel in Combination on Prostate Cancer. Cancer Genomics Proteomics 2016;13(2):151-160.

[47] He Y, Huang H, Farischon C, Li D, Du Z, Zhang K, et al. Combined effects of atorvastatin and aspirin on growth and apoptosis in human prostate cancer cells. Oncol Rep 2017; 37(2): 953-960.

[48] Mason MD, Clarke NW, James ND, Dearnaley DP, Spears MR, Ritchie AW, et al. Adding Celecoxib With or Without Zoledronic Acid for Hormone-Naïve Prostate Cancer: Long-Term Survival Results From an Adaptive, Multiarm, Multistage, Platform, Randomized Controlled Trial. J Clin Oncol 2017; JCO. 2016.69. 0677.

[49] Zheng X, Cui XX, Gao Z, Zhao Y, Lin Y, Shih WJ, et al. Atorvastatin and celecoxib in combination inhibits the progression of androgendependent $\mathrm{LNCaP}$ xenograft prostate tumors to androgen independence. Cancer Prev Res (Phila) 2010; 3(1): 114-124.

[50] Pan C, Liu C, Lara P, Evans CP, Dall'Era M, Yap S, et al. Indomethacin to inhibit AKR1C3 intracrine androgen production and sensitizes prostate cancer (PCa) to enzalutamide. J Clin Oncol 2017; 35(6)161-161.

[51] Marnett LJ, Liedtke AJ, Penning TM, Adeniji AO, Byrns MC. Indomethacin analogs for the treatment of castrate-resistant prostate cancer. US2016/0303082 A1 (patent) 2016.

[52] Liedtke AJ, Adeniji AO, Chen M, Byrns MC, Jin Y, Christianson DW, et al. Development of potent and selective indomethacin analogues for the inhibition of AKR1C3 (type $517 \beta$-hydroxysteroid dehydrogenase/ prostaglandin $\mathrm{F}$ synthase) in castrate-resistant prostate cancer. $\mathrm{J} \mathrm{Med}$ Chem 2013; 56(6): 2429-2446.

[53] Graff JN, Beer TM. Pharmacotherapeutic management of metastatic castration-resistant prostate cancer in the elderly: focus on nonchemotherapy agents. Drugs Aging 2014; 31(12): 873-882.

[54] Deb J, Majumder J, Bhattacharyya S, Jana SS. A novel naproxen derivative capable of displaying anti-cancer and anti-migratory properties against human breast cancer cells. BMC Cancer 2014; 14(1): 567.

[55] Gobec S, Bro i P, Ri ner TL. Nonsteroidal anti-inflammatory drugs and their analogues as inhibitors of aldo-keto reductase AKR1C3: new lead compounds for the development of anticancer agents. Bioorg Med Chem Lett 2005;15(23): 5170-5175.

[56] Inoue T, Anai S, Onishi S, Miyake M, Tanaka N, Hirayama A, et al. Inhibition of COX-2 expression by topical diclofenac enhanced radiation sensitivity via enhancement of TRAIL in human prostate adenocarcinoma xenograft model. BMC urology 2013; 13(1): 1.

[57] Pandey S, Walpole C, Cabot PJ, Shaw PN, Batra J, Hewavitharana AK. Selective anti-proliferative activities of Carica papaya leaf juice extracts against prostate cancer. Biomedicine \& Pharmacotherapy 2017; 89: 515523.

[58] Huang H, Li LJ, Zhang HB, Wei AY. Papaverine selectively inhibits human prostate cancer cell (PC-3) growth by inducing mitochondrial mediated apoptosis, cell cycle arrest and downregulation of NF-kappaB/ PI3K/Akt signalling pathway. J BUON; 22(1): 112-118. 
[59] He Y, Du Z, Ma S, Cheng S, Jiang S, Liu Y, et al. Biosynthesis, antibacterial activity and anticancer effects against prostate cancer (PC-3) cells of silver nanoparticles using Dimocarpus Longan Lour. Nanoscale Research Letters 2016; 11(1): 1-10.

[60] Mukherjee S, Siddiqui MA, Dayal S, Ayoub YZ, Malathi K. Epigallocatechin-3-gallate suppresses proinflammatory cytokines and chemokines induced by Toll-like receptor 9 agonists in prostate cancer cells. J Inflamm Res 2014; 7: 89.

[61] Shabana S, Siddiqui I, Khan N, Adhami V, Khan Q. Anti-Proliferative and Pro-Apoptotic Effects of (-)-Epigallocatechin-3-Gallate Encapsulated in Chitosan Nanoparticles on Human Prostate Carcinoma Cells. J Pharmaceu Pharmacol 2014; 2(1):8.

[62] Moses MA, Henry EC, Ricke WA, Gasiewicz TA. The heat shock protein 90 inhibitor, (-)-epigallocatechin gallate, has anticancer activity in a novel human prostate cancer progression model. Cancer Prev Res (Phila); 8(3): 249-257.

[63] Mayr C, Wagner A, Neureiter D, Pichler M, Jakab M, Illig R, et al. The green tea catechin epigallocatechin gallate induces cell cycle arrest and shows potential synergism with cisplatin in biliary tract cancer cells BMC Complement Alternat Med 2015; 15(1): 194.

[64] Hagen RM, Chedea VS, Mintoff CP, Bowler E, Morse HR, Ladomery MR. Epigallocatechin-3-gallate promotes apoptosis and expression of the caspase 9a splice variant in PC3 prostate cancer cells. Int J Oncol 2013; 43(1): 194-200.

[65] Gupta S, Ahmad N, Nieminen A, Mukhtar H. Growth inhibition, cellcycle dysregulation, and induction of apoptosis by green tea constituent (-)-epigallocatechin-3-gallate in androgen-sensitive and androgeninsensitive human prostate carcinoma cells. Toxicol Appl Pharmacol 2000; 164(1): 82-90.

[66] Gupta S, Hussain T, Mukhtar H. Molecular pathway for (-)-epigallocatechin-3-gallate-induced cell cycle arrest and apoptosis of human prostate carcinoma cells. Arch Biochem Biophys 2003; 410(1): 177-185.

[67] Balasubramanian S, Adhikary G, Eckert RL. The Bmi-1 polycomb protein antagonizes the (-)-epigallocatechin-3-gallate-dependent suppression of skin cancer cell survival. Carcinogenesis; 31(3): 496-503.

[68] Fang MZ, Wang Y, Ai N, Hou Z, Sun Y, Lu H, et al. Tea polyphenol (-)-epigallocatechin-3-gallate inhibits DNA methyltransferase and reactivates methylation-silenced genes in cancer cell lines. Cancer Res 2004; 64(7 Supplement): 365-365.

[69] Lee WJ, Shim JY, Zhu BT. Mechanisms for the inhibition of DNA methyltransferases by tea catechins and bioflavonoids. Mol Pharmacol 2005; 68(4): 1018-1030.

[70] Lee Y, Kwak J, Choi H, Choi K, Kim S, Lee J, et al. EGCG suppresses prostate cancer cell growth modulating acetylation of androgen receptor by anti-histone acetyltransferase activity. Int J Mol Med 2012; 30(1): 6974.

[71] Škarydová L, Ivná L, Xiong G, Maser E, Wsól V. AKR1C3 as a potential target for the inhibitory effect of dietary flavonoids. Chem Biol Interact 2009; 178(1): 138-144

[72] Desjardins J, Grenier D. Neutralizing effect of green tea epigallocatechin-3-gallate on nicotine-induced toxicity and chemokine
(C-C motif) ligand 5 secretion in human oral epithelial cells and fibroblasts. J Investig Clin Dentistry 2012; 3(3): 189-197.

[73] Tu S, Ku C, Ho C, Chen C, Huang C, Lee C, et al. Tea polyphenol (-)-epigallocatechin-3-gallate inhibits nicotine-and estrogen-induced $\alpha$ 9-nicotinic acetylcholine receptor upregulation in human breast cancer cells. Molecul Nutrit\& Food Res 2011; 55(3): 455-466.

[74] Cheng Y, Li H, Wang H, Sun H, Liu Y, Peng S, et al. Inhibition of nicotine-DNA adduct formation in mice by six dietary constituents. Food Chem Toxicol 2003; 41(7): 1045-1050.

[75] Boyanapalli SS, Kong AT. "Curcumin, the King of Spices": Epigenetic Regulatory Mechanisms in the Prevention of Cancer, Neurological, and Inflammatory Diseases. Curr Pharmacol Report 2015; 1(2): 129-139.

[76] Hong J, Ahn K, Bae E, Jeon S, Choi H. The effects of curcumin on the invasiveness of prostate cancer in vitro and in vivo. Prostate Cancer Prostatic Dis 2006; 9(2): 147-152.

[77] Teiten M, Gaascht F, Cronauer M, Henry E, Dicato M, Diederich M. Anti-proliferative potential of curcumin in androgen-dependent prostate cancer cells occurs through modulation of the Wingless signaling pathway. Int J Oncol 2010; 38(3): 603-611.

[78] Tang L, Jin T, Zeng X, Wang JS. Lycopene inhibits the growth of human androgen-independent prostate cancer cells in vitro and in BALB/c nude mice. J Nutr; 135(2): 287-290.

[79] Santoni M, Massari F, Del Re M, Ciccarese C, Piva F, Principato G, et al. Investigational therapies targeting signal transducer and activator of transcription 3 for the treatment of cancer. Expert Opin Investig Drugs 2015; 24: 1-16.

[80] Yallapu MM, Dobberpuhl MR, Maher DM, Jaggi M, Chauhan SC. Design of curcumin loaded cellulose nanoparticles for prostate cancer. Curr Drug Metab 2012; 13(1): 120-128.

[81] Hassan HE, Carlson S, Abdallah I, Buttolph T, Glass KC, Fandy TE. Curcumin and dimethoxycurcumin induced epigenetic changes in leukemia cells. Pharm Res 2014; 32(3): 863-875.

[82] Fajardo AM, MacKenzie DA, Ji M, Deck LM, Jagt DLV, Thompson TA, et al. The curcumin analog ca27 down-regulates androgen receptor through an oxidative stress mediated mechanism in human prostate cancer cells. Prostate 2012; 72(6): 612-625.

[83] Shankar S, Srivastava RK. Involvement of Bcl-2 family members, phosphatidylinositol 3'-kinase/AKT and mitochondrial p53 in curcumin (diferulolylmethane)-induced apoptosis in prostate cancer. Int $\mathrm{J}$ Oncol 2007; 30(4): 905-918.

[84] Seo E, Wu C, Greten HJ, Efferth T. Epidermal growth factor receptors and downstream signalling pathways as cancer treatment targets for medicinal plants. Ethnopharmacology. 1st ed. Michael Heinrich, Anna K. Jager (eds). New York: John Wiley and Sons, Ltd; 2015,p.169.

[85] Kim JH, Xu C, Keum YS, Reddy B, Conney A, Kong AN. Inhibition of EGFR signaling in human prostate cancer PC-3 cells by combination treatment with beta-phenylethyl isothiocyanate and curcumin. Carcinogenesis 2006; 27(3): 475-482.

[86] Shankar S, Ganapathy S, Chen Q, Srivastava RK. Curcumin sensitizes TRAIL-resistant xenografts: molecular mechanisms of apoptosis, metastasis and angiogenesis. Mol Cancer 2008; 7(16): 7-16.

[87] Dorai T, Cao Y, Dorai B, Buttyan R, Katz AE. Therapeutic potential of 
curcumin in human prostate cancer. III. Curcumin inhibits proliferation, induces apoptosis, and inhibits angiogenesis of $\mathrm{LNCaP}$ prostate cancer cells in vivo. Prostate 2001; 47(4): 293-303.

[88] Chen Q. Curcumin-Based Anti-Prostate Cancer Agents. Anti-Cancer Agents in Medicinal Chemistry (Formerly Current Medicinal ChemistryAnti-Cancer Agents) 2015; 15(2): 138-156.

[89] Tsui K, Feng T, Lin C, Chang P, Juang H. Curcumin blocks the activation of androgen and interlukin- 6 on prostate-specific antigen expression in human prostatic carcinoma cells. J Androl 2008; 29(6) 661-668.

[90] Thangapazham RL, Shaheduzzaman S, Kim K, Passi N, Tadese A, Vahey M, et al. Androgen responsive and refractory prostate cancer cells exhibit distinct curcumin regulated transcriptome. Cancer Biology \& Therapy 2008; 7(9): 1427-1435.

[91] Dorai T, Dutcher JP, Dempster DW, Wiernik PH. Therapeutic potential of curcumin in prostate cancer-IV: Interference with the osteomimetic properties of hormone refractory C4-2B prostate cancer cells. Prostate 2004; 60(1):1-17.

[92] Dorai T, Gehani N, Katz A. Therapeutic potential of curcumin in human prostate cancer-I. curcumin induces apoptosis in both androgendependent and androgen-independent prostate cancer cells. Prostate Cancer Prostatic Dis 2000; 3(2): 84-93.

[93] Mukhopadhyay A, Banerjee S, Stafford LJ, Xia C, Liu M, Aggarwal BB. Curcumin-induced suppression of cell proliferation correlates with down-regulation of cyclin D1 expression and CDK4-mediated retinoblastoma protein phosphorylation. Oncogene 2002; 21(57): 88528861.

[94] Ji J, Huang X, Zhu H. Curcumin and its formulations: potential anticancer agents. Anti-Cancer Agents in Med Chem (Formerly Curr Med Chem-Anti-Cancer Agents) 2012; 12(3): 210-218.

[95] Sharma C, Kaur J, Shishodia S, Aggarwal BB, Ralhan R. Curcumin down regulates smokeless tobacco-induced NF- $\kappa$ B activation and COX-2 expression in human oral premalignant and cancer cells. Toxicology 2006; 228(1): 1-15.

[96] Lall RK, Syed DN, Adhami VM, Khan MI, Mukhtar H. Dietary polyphenols in prevention and treatment of prostate cancer. International J Molecul Sci 2015; 16(2): 3350-3376.

[97] Gao J, Kashfi K, Liu X, Rigas B. NO-donating aspirin induces phase II enzymes in vitro and in vivo. Carcinogenesis 2006; 27(4): 803-810.

[98] Ferruelo A, Romero I, Cabrera P, Arance I, Andrés G, Angulo J. Effects of resveratrol and other wine polyphenols on the proliferation, apoptosis and androgen receptor expression in LNCaP cells. Actas Urológicas Españolas (English Edition) 2014; 38(6): 397-404.

[99] Sheth S, Jajoo S, Kaur T, Mukherjea D, Sheehan K, Rybak LP, et al. Resveratrol reduces prostate cancer growth and metastasis by inhibiting the Akt/MicroRNA-21 pathway. PLoS One 2013;7(12):e516552013.

[100]Wang D, DuBois RN. The role of anti-inflammatory drugs in colorectal cancer. Annu Rev Med 2013;64:131-144.

[101]Stewart JR, O'Brian CA. Resveratrol antagonizes EGFR-dependent Erk1/2 activation in human androgen-independent prostate cancer cells with associated isozyme-selective PKC inhibition. Invest New Drugs 2004;22(2):107-117.
[102]Kai L, Samuel SK, Levenson AS. Resveratrol enhances p53 acetylation and apoptosis in prostate cancer by inhibiting MTA1/NuRD complex. Int J Cancer 2010;126(7):1538-1548.

[103]Jha M, Aggarwal R, Jha AK, Shrivastava A. Natural compounds: DNA methyltransferase inhibitors in oral squamous cell carcinoma. Appl Biochem Biotechnol 2015:177(3)577-594.

[104]Burgos-Moron E, Calderon-Montaño JM, Orta ML, Mateos S, LopezLazaro M. Effect Of DNA repair deficiencies on the cytotoxicity of resveratrol. Webmed Central 2015; Article ID:WMC004885.

[105]Gupta SC, Kannappan R, Reuter S, Kim JH, Aggarwal BB. Chemosensitization of tumors by resveratrol. Ann N Y Acad Sci 2011;1215(1):150-160.

[106]Jones SB, DePrimo SE, Whitfield ML, Brooks JD. Resveratrolinduced gene expression profiles in human prostate cancer cells. Cancer Epidemiol Biomarkers Prev 2005;14(3):596-604.

[107]Ren X, Bai X, Zhang X, Li Z, Tang L, Zhao X, et al. Quantitative nuclear proteomics identifies that miR-137-mediated EZH2 reduction regulates resveratrol-induced apoptosis of neuroblastoma cells. Mol Cell Proteomics 2015; 14(2):316-328.

[108]Chowdhury P, JayRoe J. Effects of a natural polyphenol on nicotineinduced pancreatic cancer cell proliferation. Tobacco Induced Dis 2014; 12(Suppl 1):A7.

[109]Csiszar A, Labinskyy N, Podlutsky A, Kaminski PM, Wolin MS, Zhang $\mathrm{C}$, et al. Vasoprotective effects of resveratrol and SIRT1: attenuation of cigarette smoke-induced oxidative stress and proinflammatory phenotypic alterations. Am J Physiol Heart Circ Physiol 2008; 294(6): H2721-35.

[110]Kode A, Rajendrasozhan S, Caito S, Yang SR, Megson IL, Rahman I. Resveratrol induces glutathione synthesis by activation of Nrf2 and protects against cigarette smoke-mediated oxidative stress in human lung epithelial cells. Am J Physiol Lung Cell Mol Physiol 2008, 294(3):L478-88.

[111]Rainsford K. Anti-inflammatory drugs in the 21 st century. Inflammation in the pathogenesis of chronic diseases. Netherlands: Springer; 2007, p. 3-27.

[112]Veitonmäki T, Murtola TJ, Talala K, Taari K, Tammela T, Auvinen A. Non-steroidal anti-inflammatory drugs and cancer death in the finnish prostate cancer screening trial. PloS One 2016; 11(4): e0153413.

[113]Rothwell PM, Price JF, Fowkes FGR, Zanchetti A, Roncaglioni MC, Tognoni G, et al. Short-term effects of daily aspirin on cancer incidence, mortality, and non-vascular death: analysis of the time course of risks and benefits in 51 randomised controlled trials. The Lancet 2012; 379(9826): 1602-1612

[114]Liu Y, Chen JQ, Xie L, Wang J, Li T, He Y, et al. Effect of aspirin and other non-steroidal anti-inflammatory drugs on prostate cancer incidence and mortality: a systematic review and meta-analysis. $B M C$ Med; 12: 55-7015-12-55.

[115]Vidal AC, Howard LE, Moreira DM, Castro-Santamaria R, Andriole GL, Freedland SJ. Aspirin, NSAIDs, and risk of prostate cancer: results from the REDUCE study. Clin Cancer Res; 21(4): 756-762.

[116]Basudhar D, Cheng RC, Bharadwaj G, Ridnour LA, Wink DA, Miranda KM. Chemotherapeutic potential of diazeniumdiolate-based aspirin 
prodrugs in breast cancer. Free Radical Biol Med 2015; 83: 101-114.

[117]Ng K, Meyerhardt JA, Chan AT, Sato K, Chan JA, Niedzwiecki D, et al. Aspirin and COX-2 inhibitor use in patients with stage III colon cancer. J Natl Cancer Inst 2014; 107(1): 345.

[118]Zhang Y, Liu L, Fan P, Bauer N, Gladkich J, Ryschich E, et al. Aspirin counteracts cancer stem cell features, desmoplasia and gemcitabine resistance in pancreatic cancer. Oncotarget 2015; 6(12): 9999-10015.

[119]Muranushi C, Olsen CM, Pandeya N, Green AC. Aspirin and nonsteroidal anti-inflammatory drugs can prevent cutaneous squamous cell carcinoma: a systematic review and meta-analysis. J Invest Dermatol 2015; 135(4): 975-983.

[120]Gala MK, Chan AT. Molecular pathways: aspirin and Wnt signaling-a molecularly targeted approach to cancer prevention and treatment. Clin Cancer Res 2015;21(7):1543-1548.

[121]Van Kruijsdijk RC, Visseren FL, Ridker PM, Dorresteijn JA, Buring JE, van der Graaf $\mathrm{Y}$, et al. Individualised prediction of alternate-day aspirin treatment effects on the combined risk of cancer, cardiovascular disease and gastrointestinal bleeding in healthy women. Heart 2015; 101(5): 369-376.

[122]Olivan M, Rigau M, Colás E, Garcia M, Montes M, Sequeiros T, et al. Simultaneous treatment with statins and Aspirin reduces the risk of prostate cancer detection and tumorigenic properties in prostate cancer cell lines. BioMed Res Int 2015; 2015: 762178.

[123]Rotem R, Tzivony Y, Flescher E. Contrasting effects of aspirin on prostate cancer cells: suppression of proliferation and induction of drug resistance. Prostate 2000; 42(3): 172-180.

[124]Bilani N, Bahmad H, Abou-Kheir W. Prostate cancer and Aspirin use: Synopsis of the proposed molecular mechanisms. Frontiers in Pharmacology 2017; 8:145.

[125]Vidal AC, Freedland SJ. Aspirin and prostate cancer prevention. Aging (Albany NY) 2015;7(5):292-293.

[126]Barton MK. Daily aspirin may reduce mortality from prostate cancer with risk of high recurrence. CA: A Cancer J Clin 2015;65(2):83-84.

[127]Tsioulias GJ, Go MF, Rigas B. NSAIDs and colorectal cancer control: Promise and challenges. Curr Pharmacol Rep 2015:1:295.

[128]Keating GL, Reid HM, Eivers SB, Mulvaney EP, Kinsella BT. Transcriptional regulation of the human thromboxane A 2 receptor gene by Wilms' tumor (WT) 1 and hypermethylated in cancer (HIC) 1 in prostate and breast cancers. Biochimica et Biophysica Acta (BBA)-Gene Regulatory Mechanisms 2014;1839(6):476-492.

[129]Yiannakopoulou E. Targeting epigenetic mechanisms and microRNAs by aspirin and other non steroidal anti-inflammatory agents-implications for cancer treatment and chemoprevention. Cellular Oncology 2014; 37(3): 167-178

[130]Noreen F, Roosli M, Gaj P, Pietrzak J, Weis S, Urfer P, et al. Modulation of age- and cancer-associated DNA methylation change in the healthy colon by aspirin and lifestyle. J Natl Cancer Inst 2014; 106(7):10.1093/ jnci/dju161

[131]Passacquale G, Phinikaridou A, Warboys C, Cooper M, Lavin B,
Alfieri A, et al. Aspirin-induced histone acetylation in endothelial cells enhances synthesis of the secreted isoform of netrin-1 thus inhibiting monocyte vascular infiltration. Br J Pharmacol 2015; 172(14): 35483564.

[132]Jung YR, Kim EJ, Choi HJ, Park J, Kim H, Lee Y, et al. Aspirin targets SIRT1 and AMPK to induce senescence of colorectal carcinoma cells. Mol Pharmacol 2015; 88(4): 708-719.

[133]Sonnemann J, Hüls I, Sigler M, Palani CD, Hong LTT, Völker U, et al. Histone deacetylase inhibitors and aspirin interact synergistically to induce cell death in ovarian cancer cells. Oncol Rep 2008; 20(1): 219224

[134]Lim JT, Piazza GA, Pamukcu R, Thompson WJ, Weinstein IB Exisulind and related compounds inhibit expression and function of the androgen receptor in human prostate cancer cells. Clin Cancer Res 2003; 9(13): 4972-4982.

[135]Lovering AL, Ride JP, Bunce CM, Desmond JC, Cummings SM White SA. Crystal structures of prostaglandin D(2) 11-ketoreductase (AKR1C3) in complex with the nonsteroidal anti-inflammatory drugs flufenamic acid and indomethacin. Cancer Res 2004; 64(5): 1802-1810.

[136]Uwakwe A, Monanu M. In vitro effects of aspirin and paracetamol on human erythrocyte glutathione-s-transferase activity. Glob J Med Sci 2004; 3(1): 33-36.

[137]Harris RE, Beebe-Donk J, Schuller HM. Chemoprevention of lung cancer by non-steroidal anti-inflammatory drugs among cigarette smokers. Oncol Rep 2002; 9(4): 693-695.

[138]Qin S, Xu C, Li S, Yang C, Sun X, Wang X, et al. Indomethacin induces apoptosis in the EC109 esophageal cancer cell line by releasing second mitochondria-derived activator of caspase and activating caspase-3. Molecul Med Report 2015; 11(6): 4694-4700.

[139]Valle BL, D'Souza T, Becker KG, Wood III WH, Zhang Y, Wersto RP, et al. Non-steroidal anti-inflammatory drugs decrease E2F1 expression and inhibit cell growth in ovarian cancer cells. PLoS One 2013; 8(4): e61836.

[140]Curry JM, Besmer DM, Roy LD, Grover P, Nath S, Rao S, et al. Combinational treatment with MUC1 vaccine and Indomethacin reduces breast tumor burden via a COX-independent pathway. Cancer Res 2013; 73(8 Supplement): 475-475.

[141]Cousido-Siah A, Ruiz FX, Crespo I, Porté S, Mitschler A, Parés X, et al. Structural analysis of sulindac as an inhibitor of aldose reductase and AKR1B10. Chem Biol Interact 2015; 234: 290-296.

[142]Cipollina C, Di Vincenzo S, Gerbino S, Siena L, Gjomarkaj M, Pace E. Dual anti-oxidant and anti-inflammatory actions of the electrophilic cyclooxygenase-2-derived 17-oxo-DHA in lipopolysaccharide-and cigarette smoke-induced inflammation. Biochimica et Biophysica Acta (BBA)-General Subjects 2014; 1840(7): 2299-2309.

[143]Gund M, Khan FN, Khanna A, Krishnakumar V. Nicotinic acid conjugates of nonsteroidal anti-inflammatory drugs (NSAID's) and their anti-inflammatory properties. European J Pharmaceut Sci 2013; 49(2): $227-232$. 